\title{
Provision of Recreational Facilities in Asokoro District, Abuja, Nigeria
}

\author{
Bogoro Audu Gani \\ Abubakar Tafawa Balewa University, Bauchi, Nigeria
}

\begin{abstract}
Recreation is an activity of leisure, leisure being discretionary time. Recreation is an activity that people engage in during their free time. It is an essential part of human life and the role recreation plays in our societies has to do with health benefits, economic development, and prevention of crime. This paper is aimed at reviewing the provisions of recreational facilities in Asokoro District with a view to make appropriate planning recommendations. The methods of data collection are primary and secondary sources. The analysis is based on the responses of 302 respondents, from different recreational centers and general public. Different parameters were used to retrieve the information, which was based on socioeconomic, socio-cultural, and physical aspects. The summary of findings revealed that more than $75 \%$ of the respondents are high income adults who are interested in recreational activities The major problems facing recreation in the area include, encroachment by other land uses long distance, inadequacy and poor maintenance of the recreational facilities. It is recommended that more facilities to be provided in accordance with planning standards and also space allocated for the development of recreational facilities in the districts should be protected by planning laws and regulations.
\end{abstract}

Keyword: recreation, facilities, provision, activity, leisure

\section{INTRODUCTION}

Recreation can improve your health and reduce the risk of developing several diseases it can also have immediate and long-term health benefits. Most importantly, regular activity can improve your quality of life. Land use changes in Asokoro District has been identified as one of the problems which result in poor planning and development of open spaces for provision of recreation in the area. In the case where the provision of recreational facilities is adequate, poor management and the maintenance of the facilities is always a major problem. It is expedient to examine the existing recreational facilities within Asokoro District as basis for determining the adequacy of facilities and problems associated with the provision of recreational facilities so as to make appropriate planning recommendations. Clawson and Knetch (1966) reviewed recreation as "basically a renewal or preparation for routine or necessary work or means of escape from it". Abraham (1981) defined recreation as "any activity voluntarily undertaken for pleasure, fun, relaxation, exercise, self-expression or release from boredom, worry or tension that which is physically or psychologically rejuvenating because it is a part from essential routine of one's life. Arthur (1997) said; "Recreation involves the use of open space to pursuit leisure activities, and the vehicle for promoting cultural and civic expression. Recreation facilities are the physical assets which accommodate recreation activities. They can be natural or built assets which are specifically provided and managed for recreational purposes or they may be assets which fulfill some other primary role and which are occasionally used for recreation. Demand for recreational facilities refers to the number of visitors or users of any recreational resources, therefore, for the purpose of this research, demand can be defined as the number of persons or unit of participants required to take part in a particular recreational activity. (Burton 1985) No one would ever understand the importance of recreation till the time they experience the values and benefits of it on their own. It is more of a fun embodied in the form of activities to refresh one's body and mind.

1. Helps You Relax - Recreational activities help you relax and give soothing effect to your nerves. 
It helps you release the tension and maintain equilibrium. It is one of the best relaxation techniques to help you get back to work in full form.

2. Impacts Your Health- Recreational activities have a very good impact on your health. It is an excellent medicine for ailments which cannot be cured by any other manner. It is a natural way to stay fit and healthy in life.

3. Refills the Energy- Recreation activities are best mechanism to refill your energy and make you feel alive again. It is best way to charge you up when you feel exhausted and drained out.

\section{Economic Development-Recreation} is importance in the development of economy structure of the country and the participant through the gift, foreign exchange transfers to the participants. For instance in the transfer of the footballer from one area to another.

5. Quality of Life- Recreational activities help you build self-esteem and confidence. It helps you enhance the quality of life by building a positive self-image.

6. Effective Time Utilization- When your body is at the better of its form both in terms of health and energy, recreational activities helps you utilize your time effectively. The effort you put in a certain task is way below what you could have possibly put without any recreational activity.

7. Sharpen Skills- The value and benefit of recreational activities is best seen in the form of skills that gets developed and sharpened over the period of time. You not only are inclined to learn more things but are also motivated to be at your best.

8. Social Benefits- It helps you meet like-minded people and develop a favorable rapport. People, who share common interest, makea joyful group that helps each other to promote themselves. Importance of recreation gets reflected in the status you build for yourself.

Recreation, like work, love and worship, has been an important aspect of life for centuries. Moreover, music, dances, games, and festivals have always been part of life. Therefore, recreation plays an important role in the life of an individual, community and nation. People get stimulated into recreation only if the facilities are available. With available facilities, there will be increase in recreational activities and participation. Factors influencing participation in recreational activities include age, sex, income level, time factor and physical factor. Standard for recreational facilities are guidelines or rules which guides the recreational planners to determine the type and number of recreational facility to be provided based on the population size and characteristics. The use of planning standards has also been criticized based on the fact that recreation element and pattern is affected by time, cultural background and income as well as with age and fashion. Onokerhoraye (1982) echoed on British National Playing Field Association (1925) recommended that there should be about two (2) hectares of land per 1,000 people for recreational purpose in form of parks, sport ground, golf coasts etc. as in table $1-4$.

Various approaches to recreational planning exist and have been used. An approach may be different from another based on different emphasis on how recreation is seen and defined by the planner. However, in a nut shell the approach is an attempt to meet up the demand generated that manifest spatially.

\section{MATERIALS AND METHODS}

Abuja, the capital city of Nigeria is located in the geographical centre of Nigeria. It has a land area of 8,000 square Kilometers. It is bounded on the north by Kaduna state, on the west by Niger state, on the east and south-east by Nasarawa state and on the south-west by Kogi state. It falls within latitude $745^{\prime}$ and 7 39'. While Asokoro District in Abuja, lies on $9^{\circ}$ 3' 7' North, $7^{\circ} 31^{\prime} 48^{\prime \prime}$ South as shown in the figures 1 and 2 below

Abuja under Köppen climate classification features a tropical wet and dry climate. The FCT experiences three weather conditions annually. This includes a warm, humid rainy season and a blistering dry season. In between the two, there is a brief interlude of harmattan occasioned by the northeast trade wind, with the main feature of dust haze, intensified coldness and dryness.

The rainy season begins from March and ends in October, when daytime temperatures reach $28{ }^{\circ} \mathrm{C}$ $\left(82.4^{\circ} \mathrm{F}\right)$ to $30^{\circ} \mathrm{C}\left(86.0^{\circ} \mathrm{F}\right)$ and night time lows hover around $22{ }^{\circ} \mathrm{C}\left(71.6^{\circ} \mathrm{F}\right)$ to $23{ }^{\circ} \mathrm{C}\left(73.4^{\circ} \mathrm{F}\right)$. In the dry season, daytime temperatures can soar as high as 40 ${ }^{\circ} \mathrm{C}\left(104.0^{\circ} \mathrm{F}\right)$ and night time temperatures can dip to $12{ }^{\circ} \mathrm{C}\left(53.6^{\circ} \mathrm{F}\right)$. Even the chilliest nights can be followed by daytime temperatures well above $30{ }^{\circ} \mathrm{C}$ $\left(86.0^{\circ} \mathrm{F}\right)$. The high altitudes and undulating terrain of the FCT act as a moderating influence on the weather 
of the territory According to the Abuja master plan, Asokoro was estimated to have a total of 30,000 people which was the planned population. However, due to the rapid increase in population and growth, the district was estimated to have a population of 71,657 people as at 2013 (getamap.com) which was used in carrying out this research. The two types of data collection used for this research are primary data and secondary data those which have already been collected and analyzed by someone. The primary sources include information obtained directly from the field by the researcher through observation, reconnaissance survey, questionnaire, and oral interview with some planning personnel in different government organizations such as Federal Capital Development Authority (FCDA), Abuja Environmental Protection Agency (AEPB), Parks and Recreation Department etc. The secondary sources were obtained through the use of necessary texts, journals, manuals, theses, photographs, past projects on recreational facilities, maps, media and online research. The technique used in this project research is the simple random sampling; it will focus on the random selection of respondents from each recreational center.

The sampling size to be used in this research using the population of the study area was obtained from the formula; $s=\frac{x^{2} N P(1-P)}{d^{2}(N-1)+x^{2} P(1-P)}$ used by Krejcie and Morgan (1970).

Where; $\mathrm{s}=$ required sample size

$x^{2}=$ the table value of chi-square for 1 degree of freedom at the desired confidence level

$\mathrm{N}=$ the population size

$\mathrm{P}=$ the population proportion of sample frame (assumed to be .50 since this would provide the maximum sample size)

$\mathrm{d}=$ the degree of accuracy expressed as a proportion (.05)

As at 2017, the overall estimated population of the study area is approximately 71,657 people. With a sampling frame of 0.50 , since the sample size required for this research is $2 \%$, of the population, therefore 302 questionnaires as considerable sampling size for the purpose of data collection. The instruments used to analyse and present the data include pictures, charts, statistical formula, plates, diagrams, frequency distribution, percentages and tables. See table 5 The table above shows that the provision of facilities according to standard is inadequate to serve for the population of Asokoro District. Also the provision of swimming pool in the District has been overstretched

\section{RECREATIONAL FACILITIES IN ASOKORO DISTRICT (see plates 1 -12)}

\section{RESULTS AND DISCUSSION}

The age group of the study area according to the survey carried out by the researcher varies, due to the growth and change in population. According to the study people below 18 years constitutes $12.58 \%$, 1825 years made up to $28.81 \%$, while $26-40$ are $32.45 \%$, 41-60 constitutes $14.24 \%$, above 60years formed $11.92 \%$ of the population Almost $60 \%$ of the population are adults who would always want to participate in recreational activity to keep fit. From the survey it is discovered that over $50 \%$ of the respondents are public and civil servants. See table 6 From the fact that majority of the people situated in Asokoro District are mostly civil servants, public servants and those engaged in business activity. The income ranges between: - Less than \#5,000, \#5,000 to $\# 10,000, \# 10,000$ to $\# 50,000$, and above as in figure 3.

The figure shows that virtually the entire area is a high income zone. They can all afford to pay for travelling cost and the cost of using the recreational facility.

In terms of adequacy, it is found that up to $48 \%$ of the respondents complained of inadequacy as shown in figure 4.

Therefore, the facilities in the district are inadequately provided and there is need for additional facilities. The residents of Asokoro attach value to recreation as indicated in their willingness to pay money in order to partake as in table 7

The high amount paid to participate in the activity indicates the value the respondents attach to recreation In addition to money, substantial distance is always covered to access recreational facility The distance to the facility ranges between $0-1 \mathrm{~km}, 1-2 \mathrm{~km}$, $2-4 \mathrm{~km}$, more than $4 \mathrm{~km}$. see table 8 .

The above table shows that the distances to the facilities provided are in close proximity to the facilities. The long distance travelled to access the facility is an indication of inadequacy of the facility. 
The problems encountered are given as accessibility, cost, inadequacy of facility and others as in table 9.

The above table shows that the percentage of the problem encountered are; Accessibility-3.31\%, cost$31.13 \%$, inadequacy of facility-39.74\%, others $25.82 \%$. This implies that the provision of facilities in the District is inadequate for the population. Most of these problems can only be solved by providing more facilities.

\section{RECOMMENDATION}

The Government should be able to involve the private sector by giving out land to prospective private developer to build or construct the recreational facility. The private sector should be involved in the provision and management of recreational centers in the district. A successful recreational development depends on the availability of facilities and services, therefore, if more facilities are provided and managed in the government owned centers, there will be more patronage by the users. The recreational space allocated for the development of recreational facilities in the districts should be protected by planning laws and regulations.. This will reduce the rampant conversion of recreational space to other land use. In the case where the land use must be changed, then there should be a trade-off between the two lands uses involved such that what is lost is gained somewhere else. Lastly, for proper management it is recommended that Government should make it mandatory to all its agencies responsible for recreational development in the Federal Capital City i.e. FCDA, AEPB, AMAC and Park and Recreation Department to organize programs and activities that will create more awareness and increase use of facilities at nominal charges to generate funds. Recreation like work, play and sleep is an essential part of human life, without it life is incomplete, dull and monotonous. Therefore, participation in recreational activity helps to achieve greatness in all aspect relating to good health and helps individual to socialize properly. Recreation is any pursuit engaged upon during leisure period other than that which is economically gainful. There is need for adequate planning and provision of recreational facilities in the Federal Capital City, the new capital city particularly Asokoro District. However, the study area has shown some problems of planning implementation and management of recreational facilities. This has been related to the issue of high influx of people and fast paced development of Abuja, trying to meet up with other developed capitals of the world.

\section{REFERENCES}

1. Adeborioye, T. and Okon, E. (1984). "The Typical Nigerian Attitude to Leisure". Sunday times, Lagos, Nigeria, October 14

2. Appleteon, I. (1974). Leisure and Policy Research, Edinburgh: Scottish Academy Press.

3. Ajiya, P. (2001). An Assessment of Facilities for Active Recreation in Abuja. ACase Study of Garki and Asokoro District, Unpublished B.tech Dissertation. Abubakar Tafawa Balewa University, Bauchi.

4. Arthur, E. (1997). Urban Planning concept, Standard and Symbol. Amifitop print Lagos.

5. Bruce C. Daniels. (1995). Puritans at play. Leisure and Recreation in Colonial New England. St Martin's Press, New York. P.xi ISBN 0-31212500-3

6. Burton, T. (1971) Experiment in Recreation Research Allen and Unwin Ltd. London.

7. Chadwick, G. F. (1966). The Park and the Town. London: Architectural Press See Chapter 1: "The English Landscape Movement and the Public Park", pp. 95-96

8. Clawson, U and Knetch, H. (1996). Economic of Outdoor Recreation, John Hopin University Press Baltimore.

9. Falade, J and Oduwaye, I. (1998).Essentials of Landscape and Site Planning. Omega H I-tech Information and Planning Systems Lagos.

10. Federal Capital Development Authority. (1979). The Master Plan for Abuja, The New Federal Capital City of Nigeria.

11. Ibrahim, U. (2001). "A Review of the Provision of Recreational Facilities within Minna Metropolis", Unpublished B.tech Dissertation. Abubakar Tafawa Balewa University, Bauchi.

12. Knudson, D. M. (1980). Outdoor Recreation, New York: Macmillan Company Inc.

13. Kalgo, M. S. U. and Olatubosun, A. (2001).“The Review of Abuja Master Plan" Ministry of the Federal Capital Territory.

14. National Population Commission (2006). Population and Housing Census, Abuja Nigeria. 
International Journal of Trend in Scientific Research and Development (IJTSRD) ISSN: 2456-6470

15. Pigram, J. (1999). Outdoor Recreation and 16. Queensland Government (2010). "What is Resource Management, London and Camberra: Recreation?" Retrieved October 31

Croom Helm.

Table 1:- Standard for Recreational Facilities

\begin{tabular}{|c|c|c|}
\hline S/N & Facility & Standard Population \\
\hline 1 & Athletic field & $1 / 20,000$ \\
\hline 2 & Beach area & $1 / 20,000$ \\
\hline 3 & Botanical garden & $1 / 100,000$ \\
\hline 4 & Library & $1 / 20,000$ \\
\hline 5 & Museum & $1 / 100,000$ \\
\hline 6 & Outdoor theatre & $1 / 100,000$ \\
\hline 7 & Picnic area & 1 acre/3,000-5,000 \\
\hline 8 & Civic center & $1 / 1,000,000$ \\
\hline 9 & Stadium & $1 / 300,000$ \\
\hline 10 & Community park & $1 / 25,000$ \\
\hline 11 & Track and field & $1 / 20,000$ \\
\hline 12 & Golf course & 18 holes $/ 50,000$ \\
\hline \multicolumn{3}{|c|}{ Source: - Arthur (1997). } \\
\hline
\end{tabular}

Table 2: Standard for Active Recreational Activities

\begin{tabular}{|c|c|c|c|}
\hline S/N & $\begin{array}{c}\text { Type of Activity } \\
\text { Space Requirement } \\
\text { Per Population }\end{array}$ & $\begin{array}{c}\text { Ideal Size of Space } \\
\text { Required for Activity }\end{array}$ \\
\hline 1 & Children play area & $0.5 \mathrm{acres} / 1,000$ & $1 \mathrm{acre}$ \\
\hline 2 & Play field area (children) & $1.5 \mathrm{acres} / 1,000$ & $3 \mathrm{acres}$ \\
\hline 3 & Play field area (adult) rend & $1.5 \mathrm{acres} / 1,000$ & $15 \mathrm{acres}$ \\
\hline 4 & Tennis, Basketball \& Baseball court & $10 \mathrm{acres} / 5,000$ & $2 \mathrm{acres}$ \\
\hline 5 & Swimming pool & 1 outdoor pool/25,000 & 2acres \\
\hline 6 & Golfing & 1 acre/50,000 & 120 acres \\
\hline
\end{tabular}

Source: - Arthur (1997).

Table 3: Standard for Passive Recreational Activities

\begin{tabular}{|c|c|c|c|}
\hline S/N & Type of Activity & $\begin{array}{c}\text { Space Requirement } \\
\text { Per Population }\end{array}$ & $\begin{array}{c}\text { Ideal Size or Space Required } \\
\text { for Activity }\end{array}$ \\
\hline 1 & Picnicking & 4 acres/1,000-2,000 & Variables \\
\hline 2 & Indoor recreation & 1 acre/10,000 & $1-2$ acres \\
\hline 3 & Outdoor activity & 1 acre/25,000 & 5 acres \\
\hline 4 & Indoor recreation & 1 acre/10,000 & $1-2$ acres \\
\hline
\end{tabular}

Source: - Arthur (1997).

Table 4: Standard for Recreational Parks

\begin{tabular}{|c|c|c|c|c|}
\hline S/N & Type of Acre & Area/100 Population & Minimum size & Radius of Area Services (Km) \\
\hline 1 & Play ground & 1.5 & 4ares/2ares & 0.75 \\
\hline 2 & Neighborhood & 2.0 & 10acres/5acres & 0.75 \\
\hline 3 & Play field & 1.5 & 15acres/10acres & 2.0 \\
\hline 4 & Community park & 3.5 & 100acres/40acres & 2.5 \\
\hline 5 & District parks & 2.0 & 200acres/100acres & 4.5 \\
\hline 6 & Regional parks & 15.0 & 500-1000acres & 15 \\
\hline
\end{tabular}

Source:- (a) George Nix, standard for new urban Dev- the Denver playground, urban land institute $1200018^{\text {th }}$ street NW Washington D.C. (b) Arthur (1997) 
International Journal of Trend in Scientific Research and Development (IJTSRD) ISSN: 2456-6470

Table 5: Analysis of Recreational Facilities In Asokoro District

\begin{tabular}{|c|c|c|c|c|}
\hline Facility & Standards & Expected Number & Existing Number & Remark \\
\hline Badminton & 4-6 courts/30,000 to 60,000 people & 5-7 Courts & 2 & Inadequate \\
\hline Table Tennis & 4-6 Tables/ 3,000 to 5,000 people & 14 Tables & 8 & Inadequate \\
\hline Swimming pool & 1 outdoor pool/ 25,000 population & 3 & 4 & Overstretch \\
\hline Football Pitch & 1 per 3,000 to 5,000 people & 5-7 Courts & 3 & Inadequate \\
\hline Volleyball & 4-6 courts/ 30,000 to 60,000 people & 5-7 Courts & 1 & Inadequate \\
\hline Basketball & 4-6 courts/ 30,000 to 60,000 people & 5-7 Courts & 1 & Inadequate \\
\hline Lawn Tennis & 4-6 courts/ 30,000 to 60,000 people & 5-7 Courts & 1 & Inadequate \\
\hline
\end{tabular}

SOURCE: Field Survey, 2017

Table 6: Occupation of respondents

\begin{tabular}{|c|c|c|}
\hline Occupation & Frequency & Percentage $(\%)$ \\
\hline Farming & - & - \\
\hline Business & 82 & 27.15 \\
\hline Civil Servants & 89 & 29.47 \\
\hline Public Servants & 66 & 21.85 \\
\hline Others & 65 & 21.53 \\
\hline Total & $\mathbf{3 0 2}$ & $\mathbf{1 0 0}$ \\
\hline
\end{tabular}

SOURCE: Field Survey, 2017

Table 7: Amount Paid For Use of Recreational Facility Weekly

\begin{tabular}{|c|c|c|}
\hline A mount & Frequency & Percentage \\
\hline Less than \#1,000 & 21 & 6.95 \\
\hline$\# 1,000-\# 2,000$ & 66 & 21.85 \\
\hline$\# 2,000-\# 5,000$ & 181 & 59.94 \\
\hline$\# 5,000$ and above & 34 & 11.26 \\
\hline Total & $\mathbf{3 0 2} 4$ & $\mathbf{1 0 0}$ \\
\hline
\end{tabular}

SOURCE: Field Survey, 2017

Table 8: Distance Taken to Facilities

\begin{tabular}{|c|c|c|}
\hline Distance Taken & Frequency & Percentage (\%) \\
\hline 0
\end{tabular}

\begin{tabular}{|c|c|c|}
\hline $0-1 \mathrm{~km}$ & 117 & 38.74 \\
\hline $1-2 \mathrm{~km}$ & 108 & 35.76 \\
\hline $2-4 \mathrm{~km}$ & 49 & 16.23 \\
\hline More than $4 \mathrm{~km}$ & 28 & 9.27 \\
\hline Total & $\mathbf{3 0 2}$ & $\mathbf{1 0 0}$ \\
\hline
\end{tabular}

SOURCE: Field Survey, 2017

Table 9: Problems Encountered

\begin{tabular}{|c|c|c|}
\hline Problems & Frequency & Percentage (\%) \\
\hline Accessibility & 10 & 3.31 \\
\hline Cost & 94 & 31.13 \\
\hline Inadequacy of facility & 120 & 39.74 \\
\hline Others & 78 & 25.82 \\
\hline Total & $\mathbf{3 0 2}$ & $\mathbf{1 0 0}$ \\
\hline
\end{tabular}

SOURCE: Field Survey, 2017 


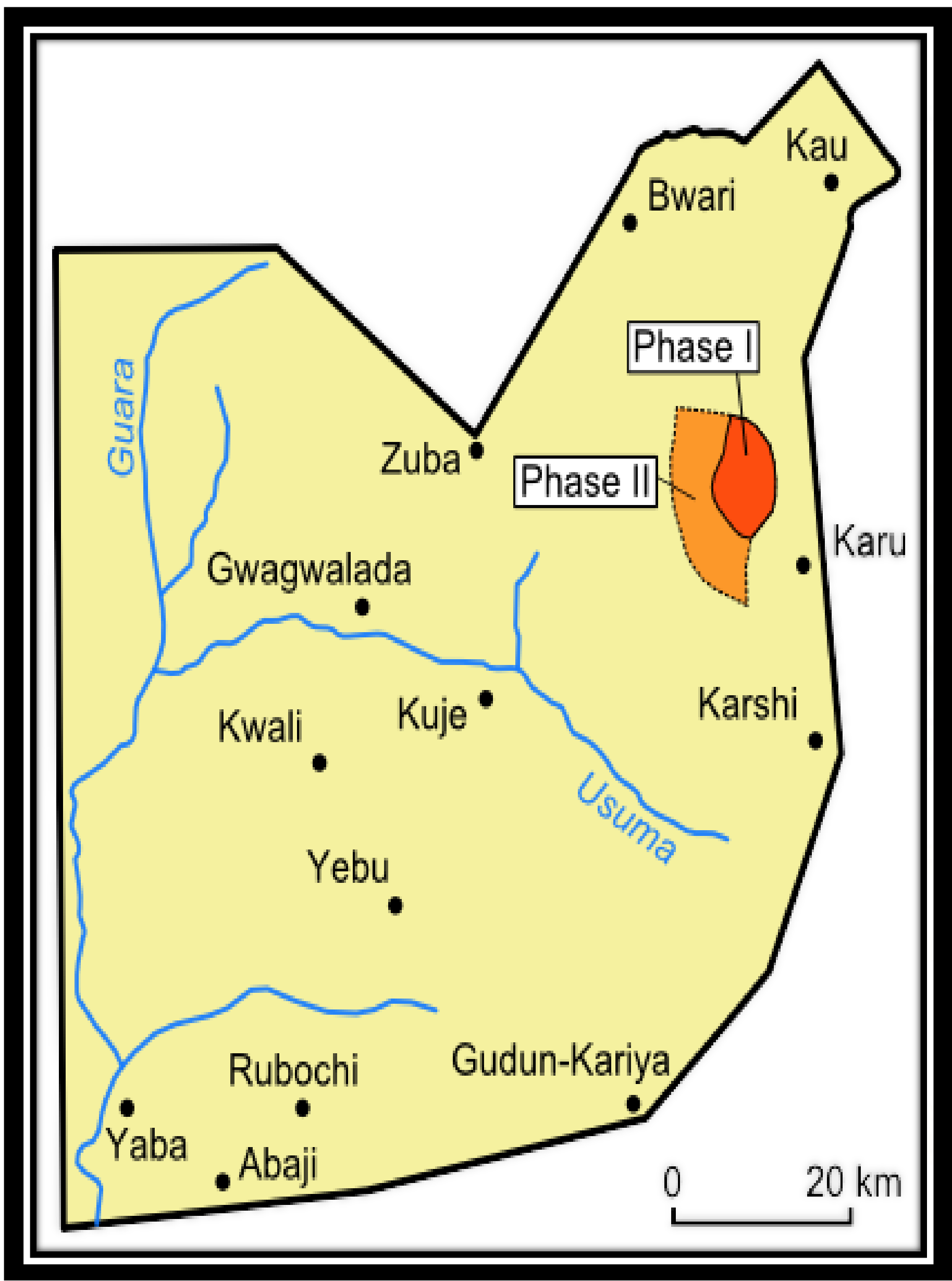

Figure 1; Map of Abuja showing Asokoro 


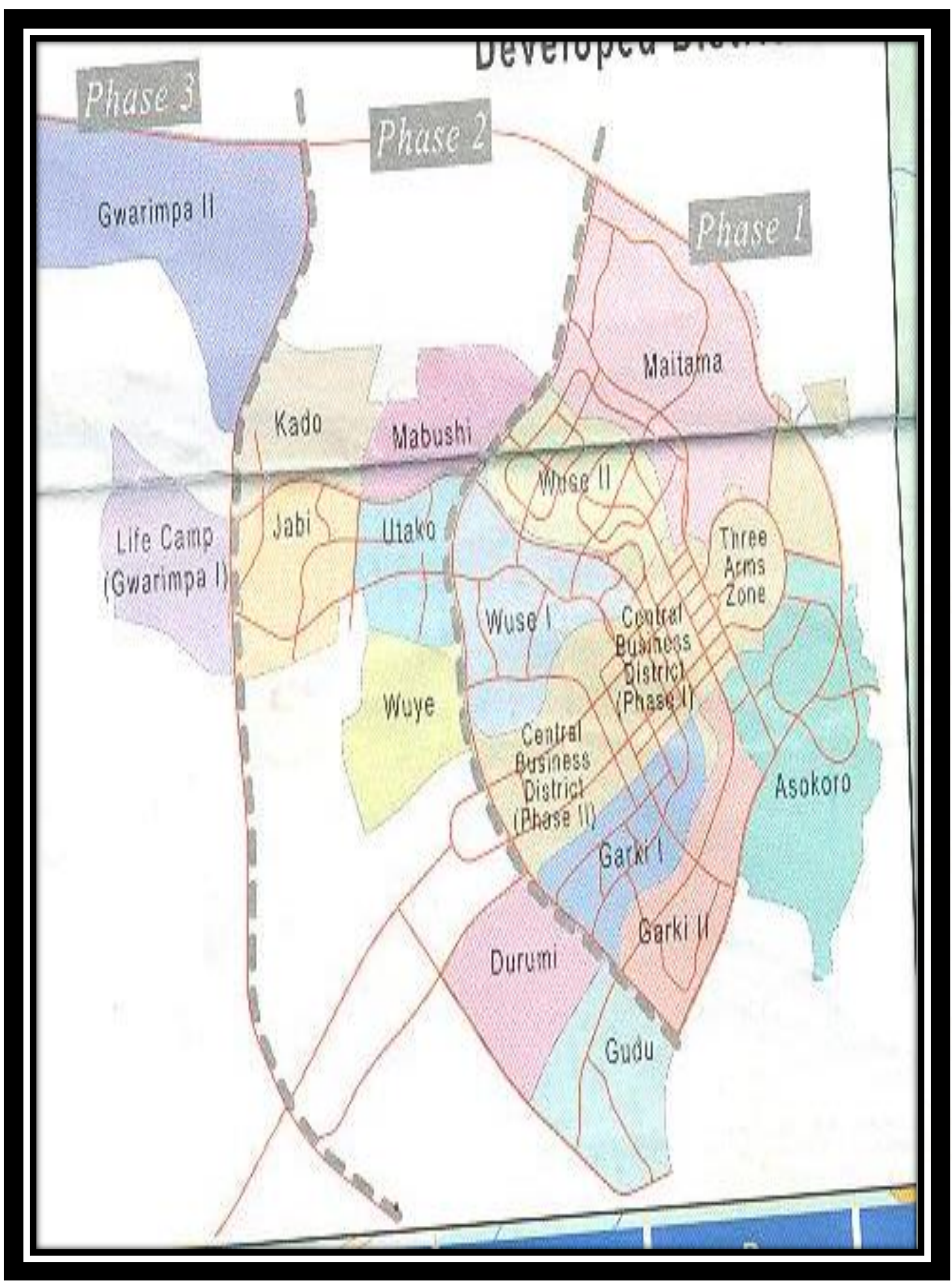

Figure 2; Map of Asokoro District 


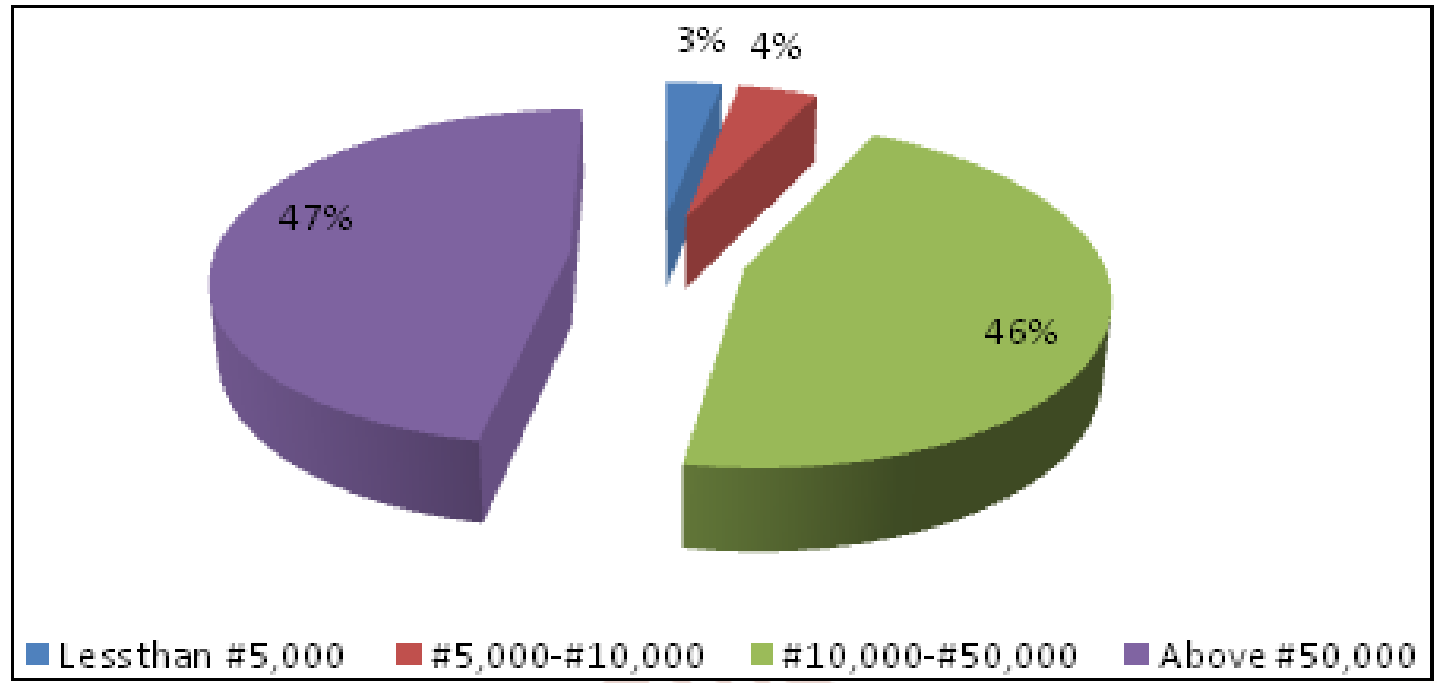

Figure 3; Income Level
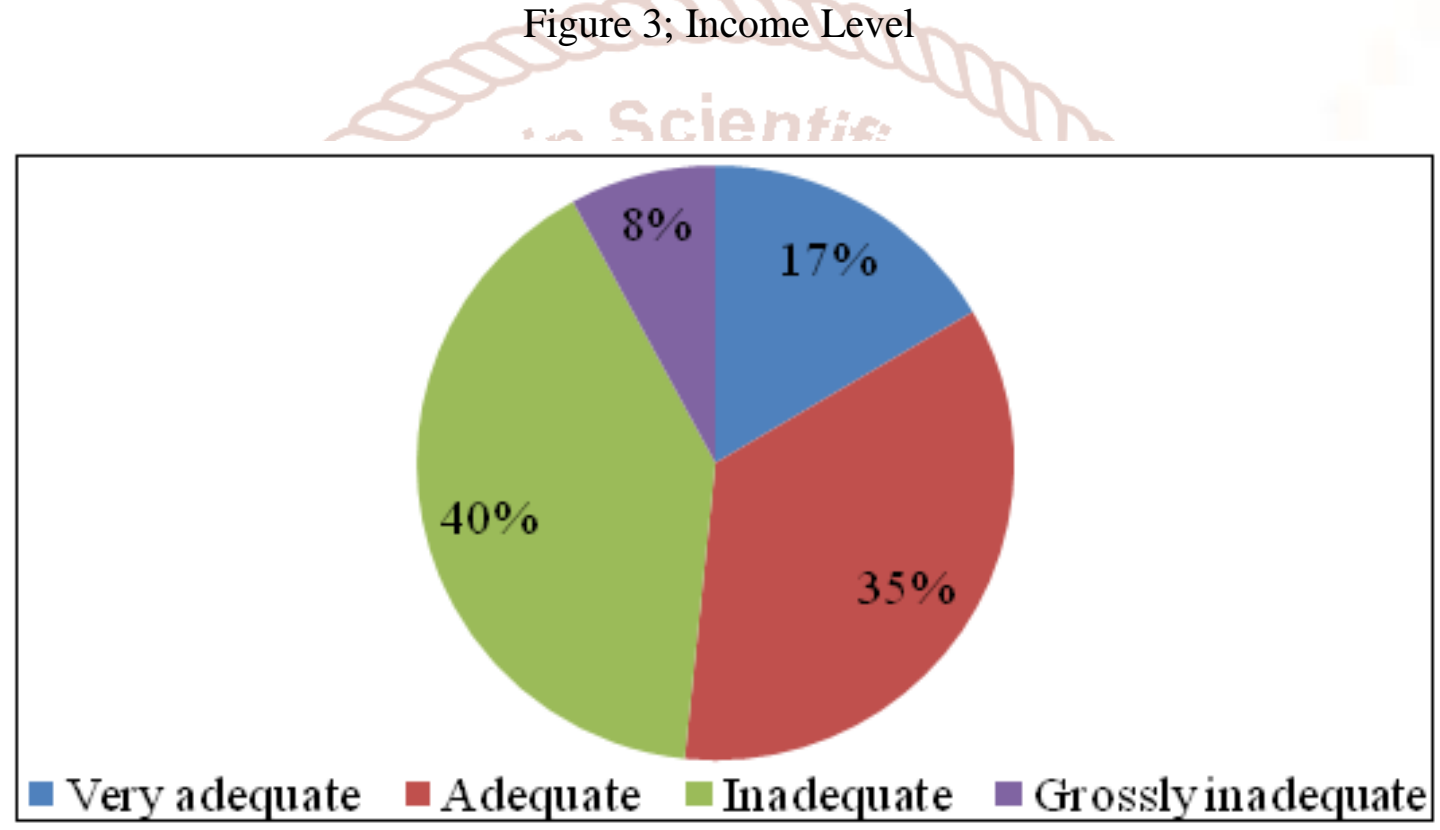

Figure 4 Distributions of Facilities

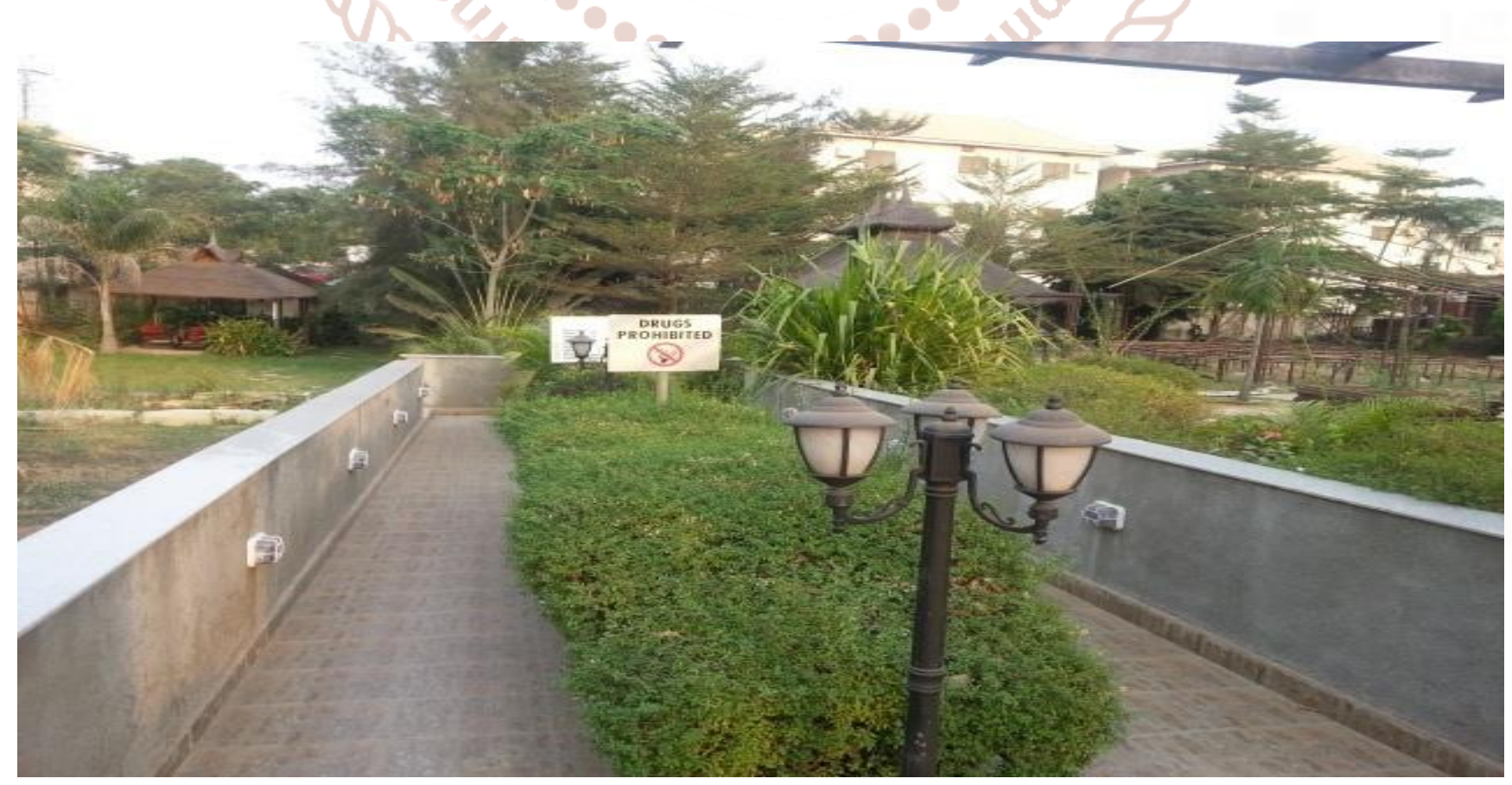

Plate 1: Entrance to Green Grass Park 


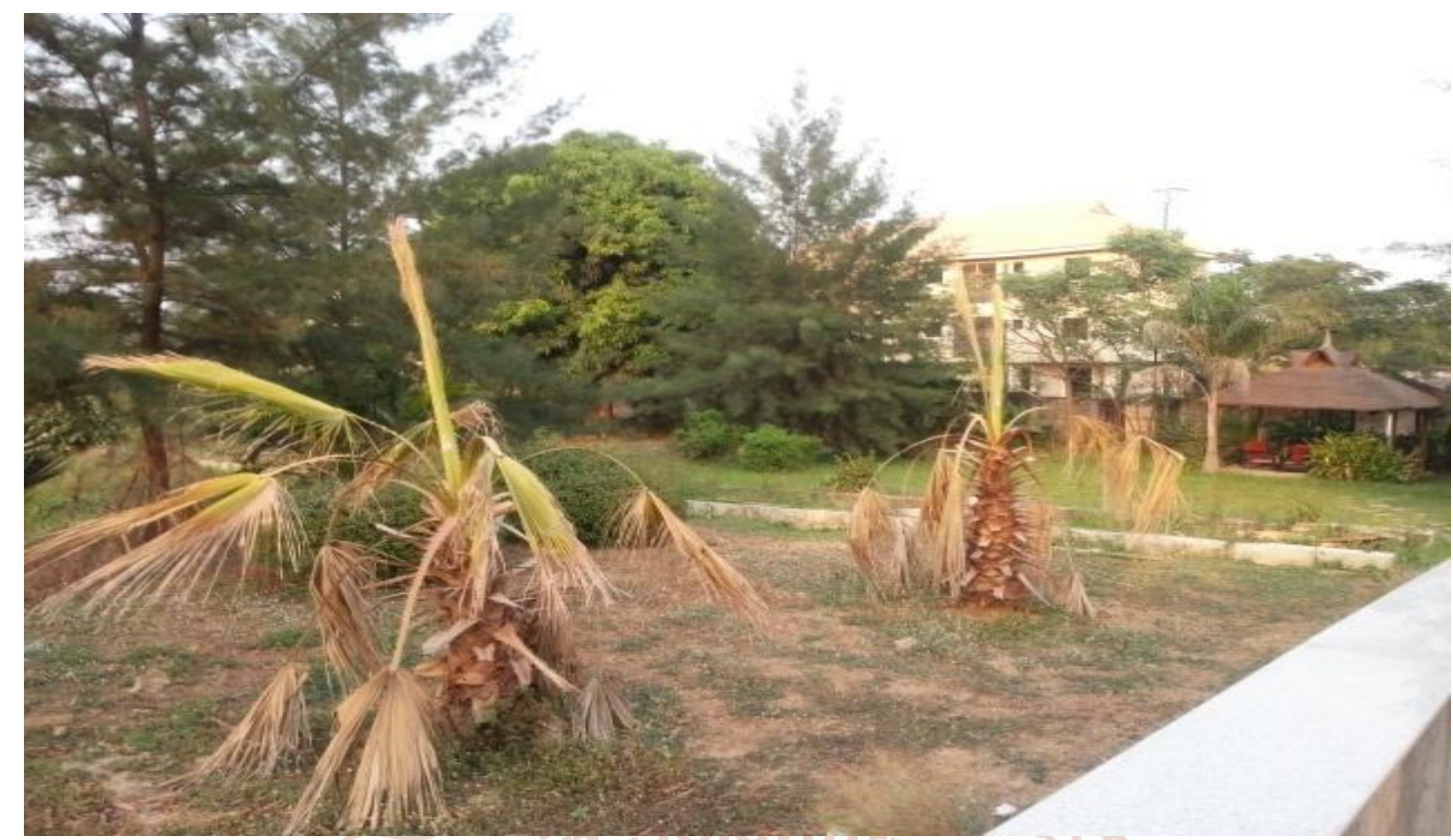

Plate 2: Dilapidated Area of Green Grass Park

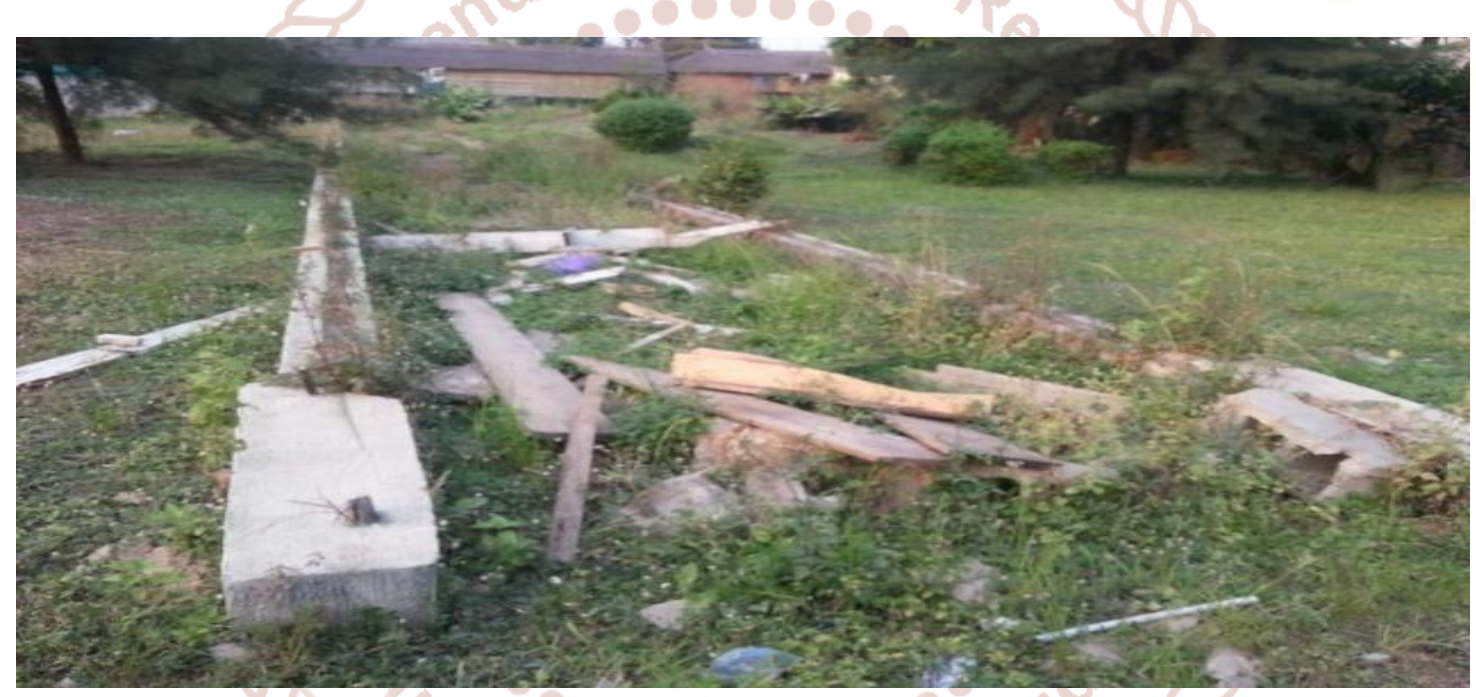

Plate 3: Broken Path Way at Green Grass Park

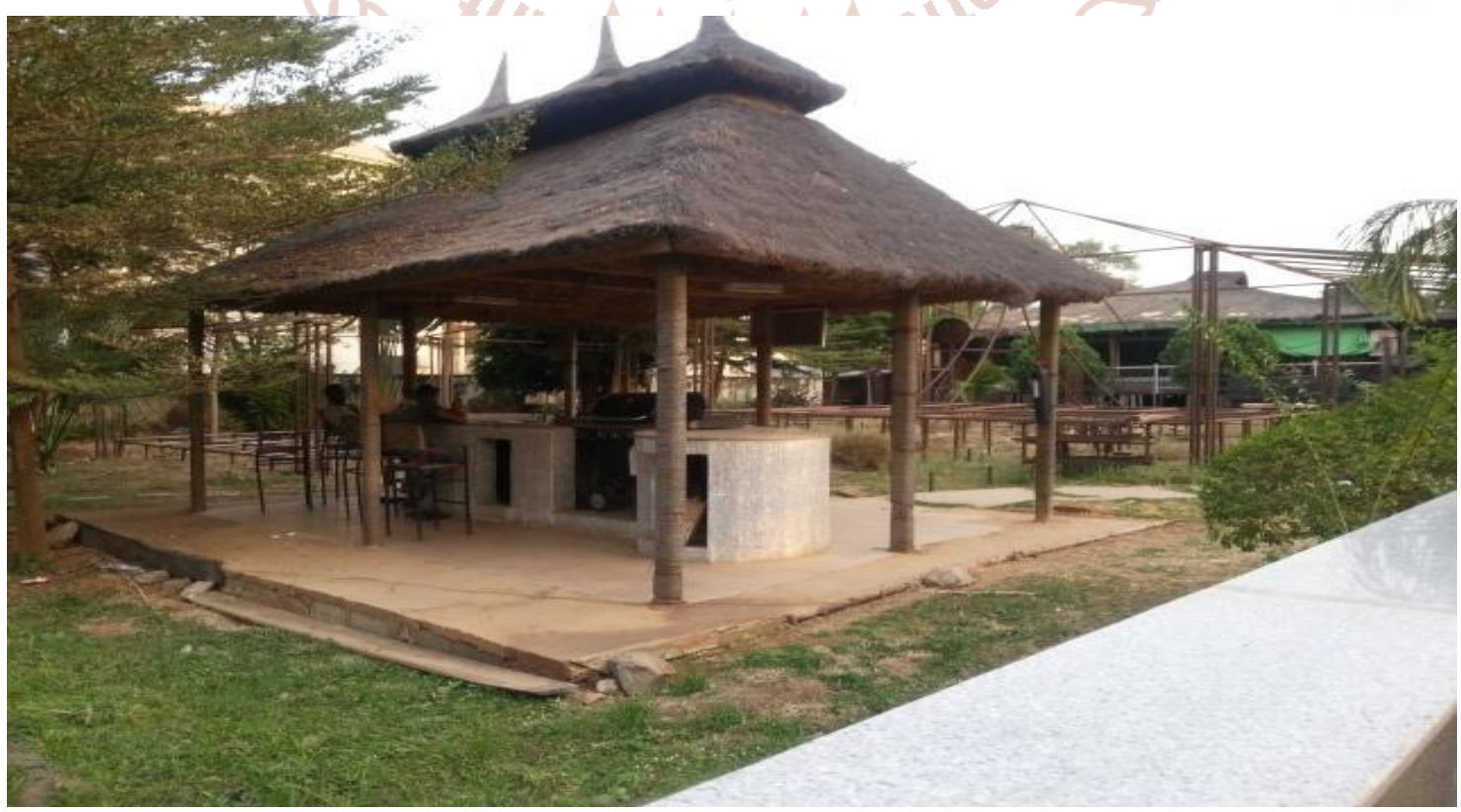

Plate 4: People Having Refreshment and Relaxing At Green Grass Park 


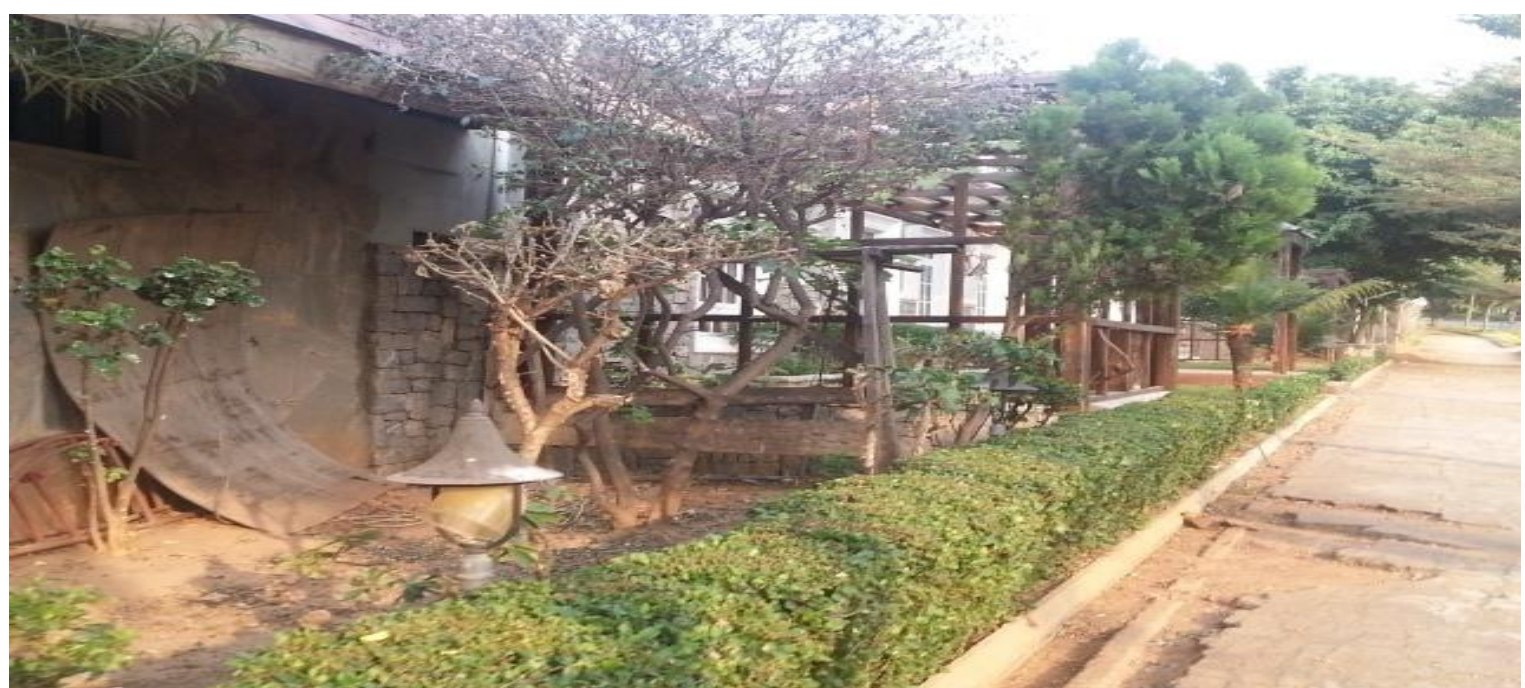

Plate 5: Side View of the Mediterrenean Recreational Club Park. Member's Only Club for both Passive and Active Recreational Activity

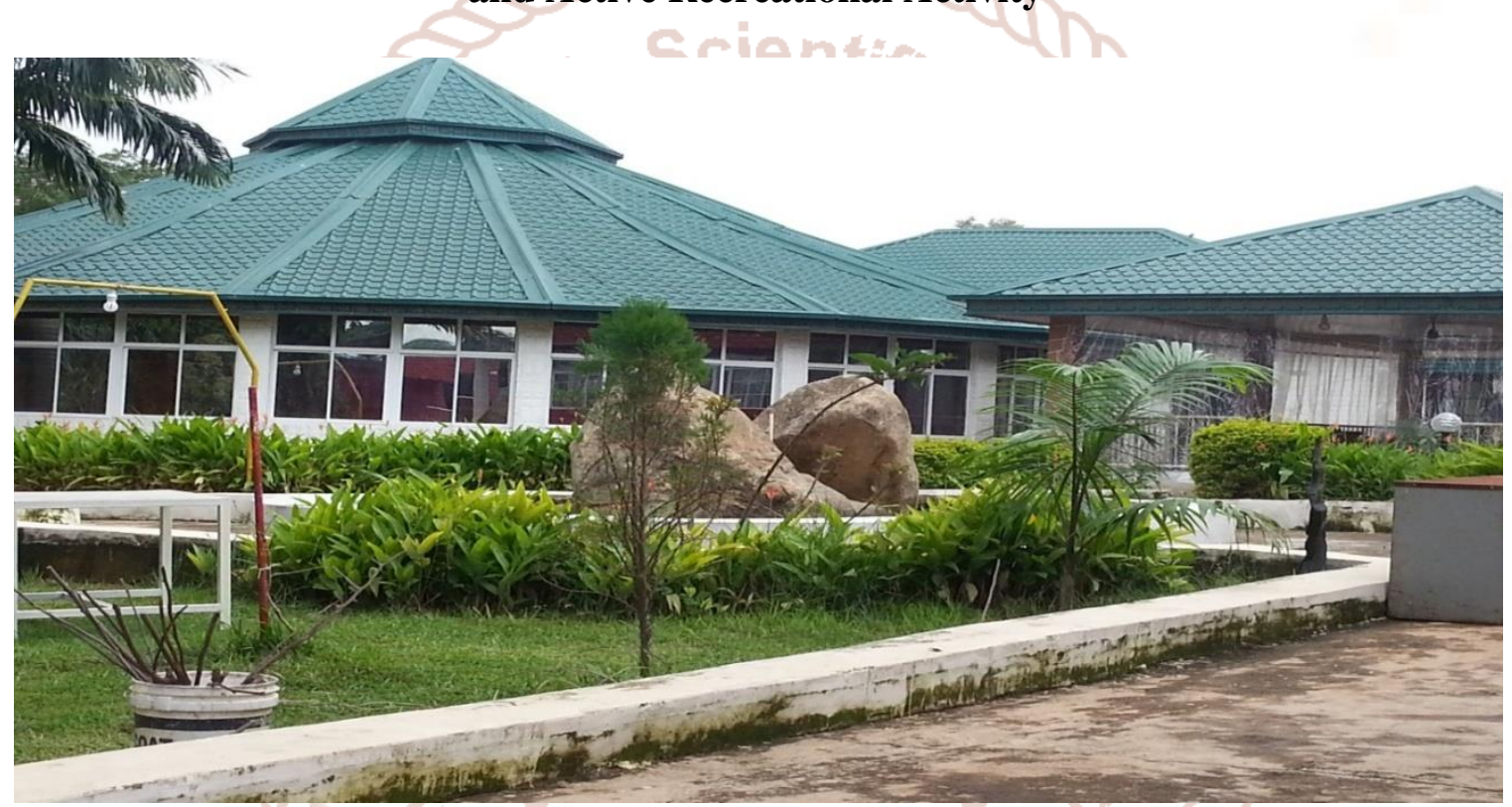

Plate 6: Monoliza Restaurant for Refreshment

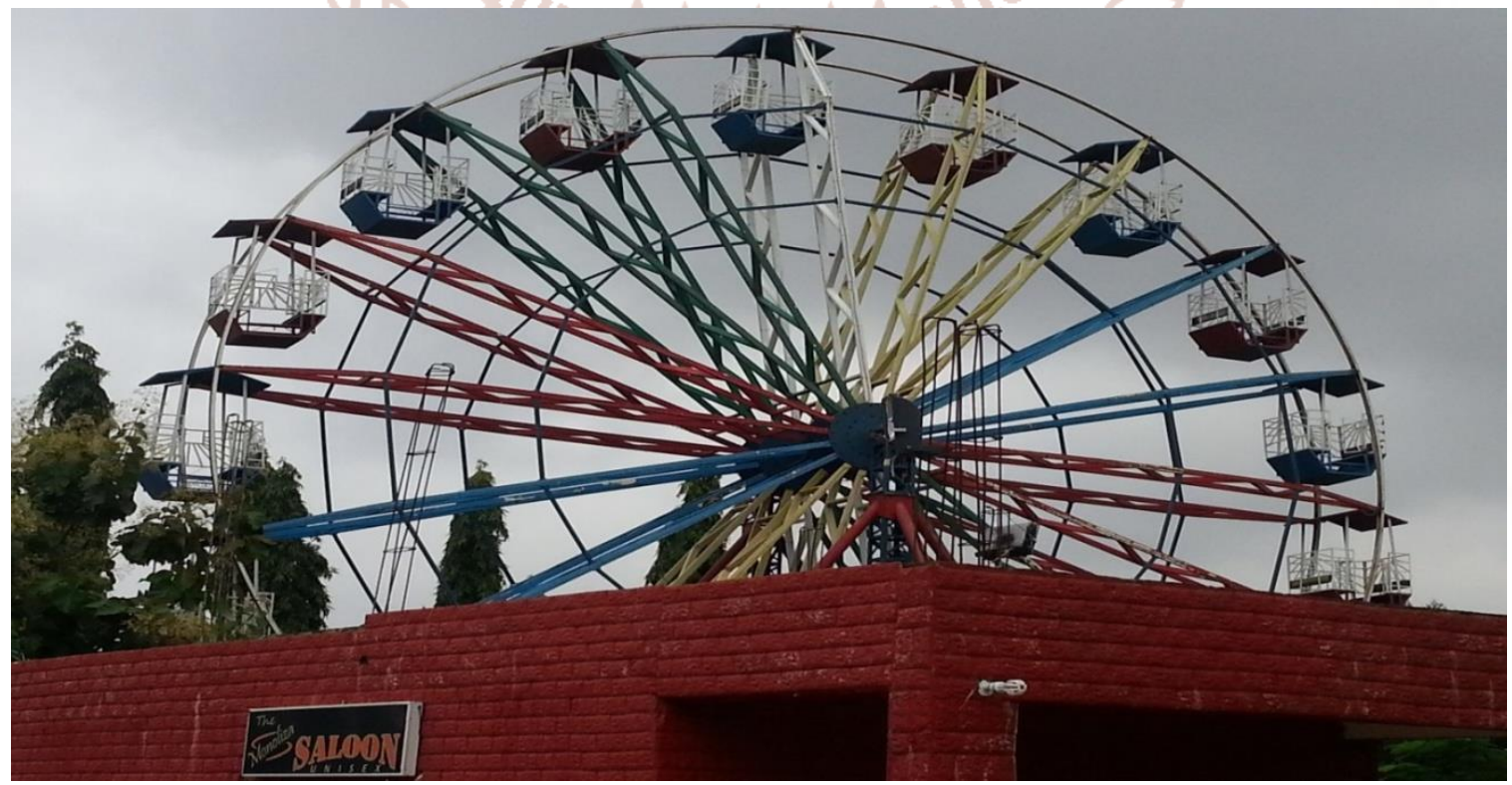

Plate 7: A Roller Coaster, Part of the Facilities at the Monoliza Amusement Park 


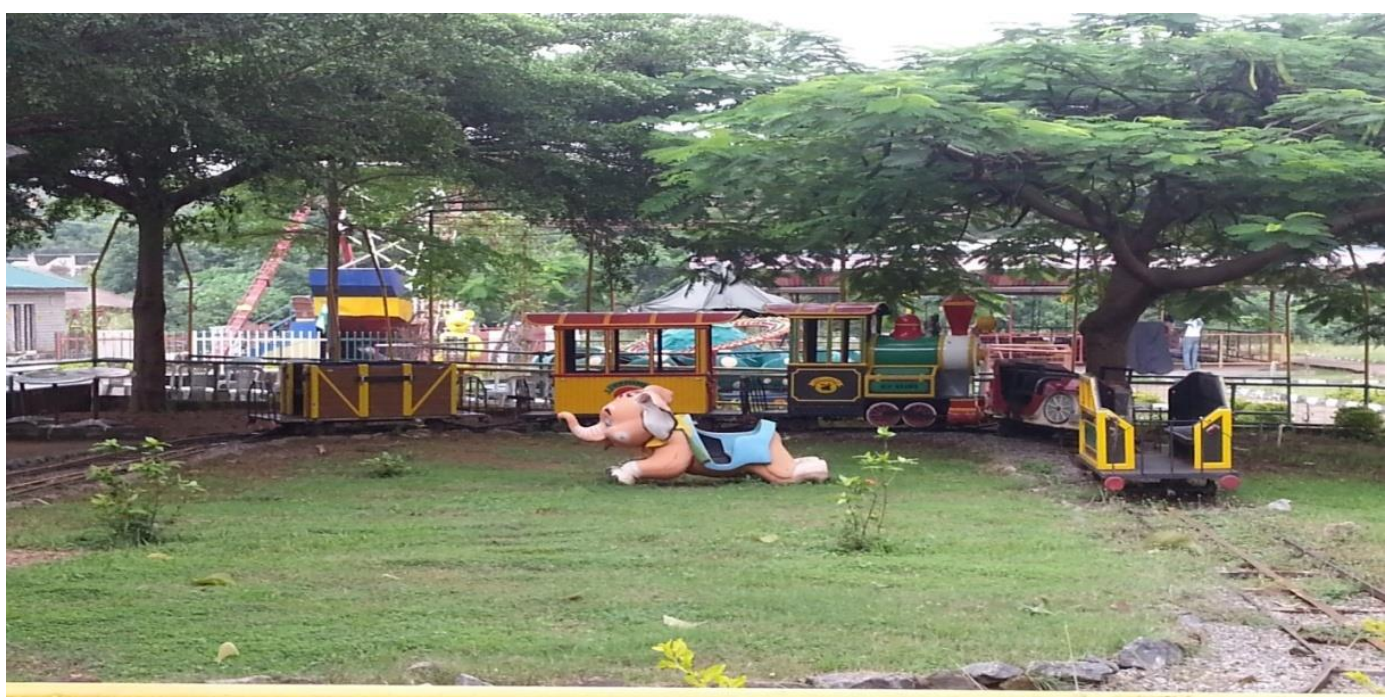

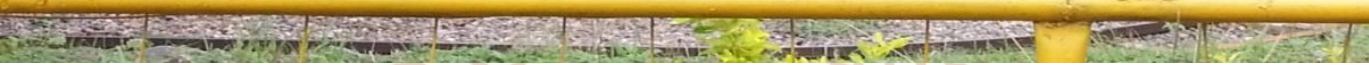

Plate 8: A Functional Train for Children at the Park

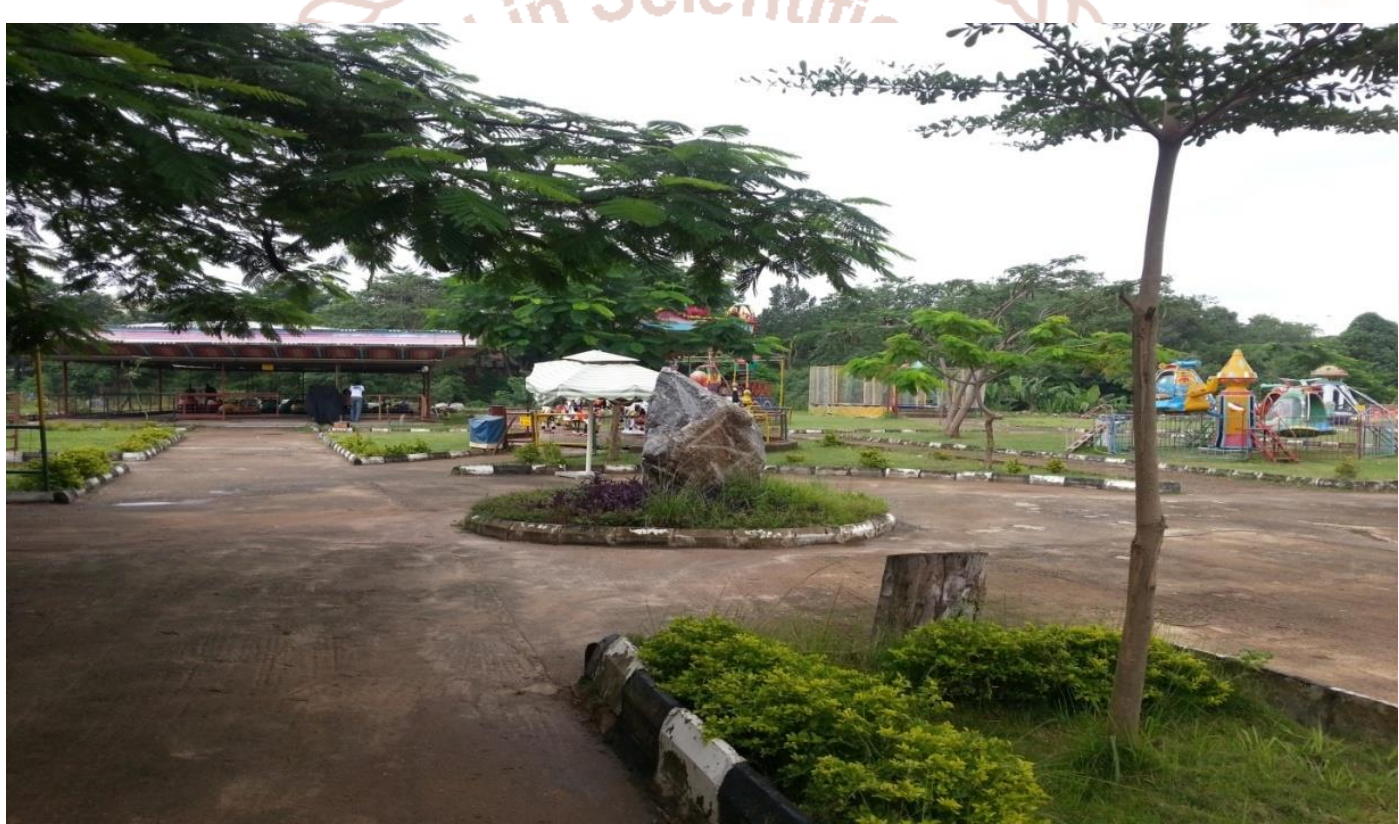

Plate 9: A View of the Park Facilitated and Maintained

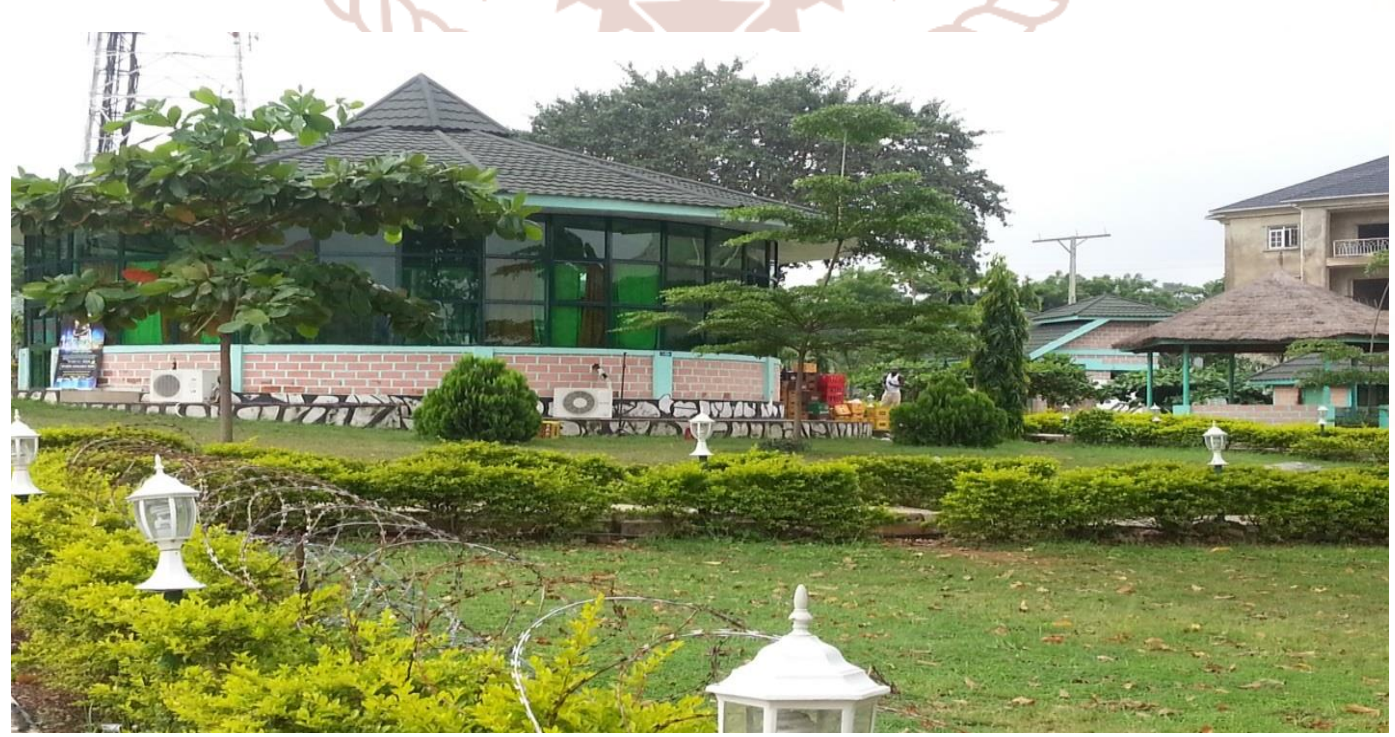

Plate 10: The Sha-Sha Recreation Center 


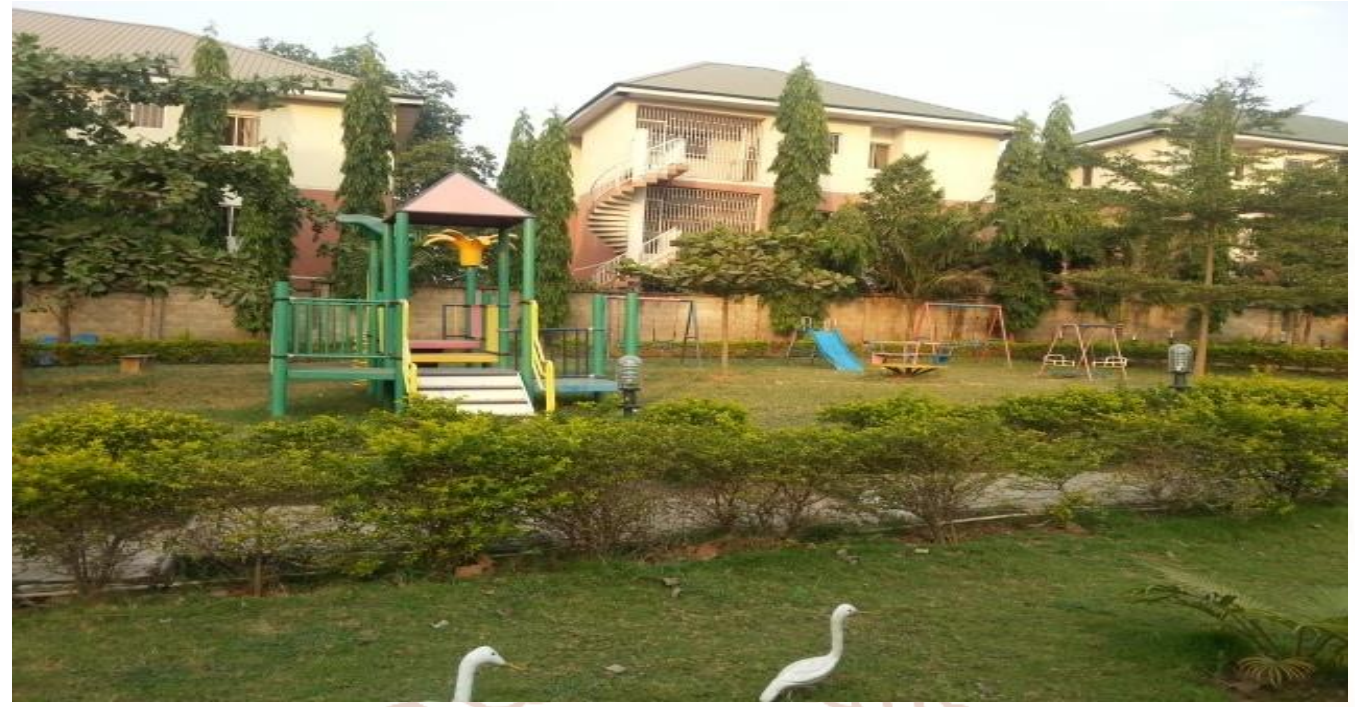

Plate 11: Children Playground at the Sha-Sha Recreational Park

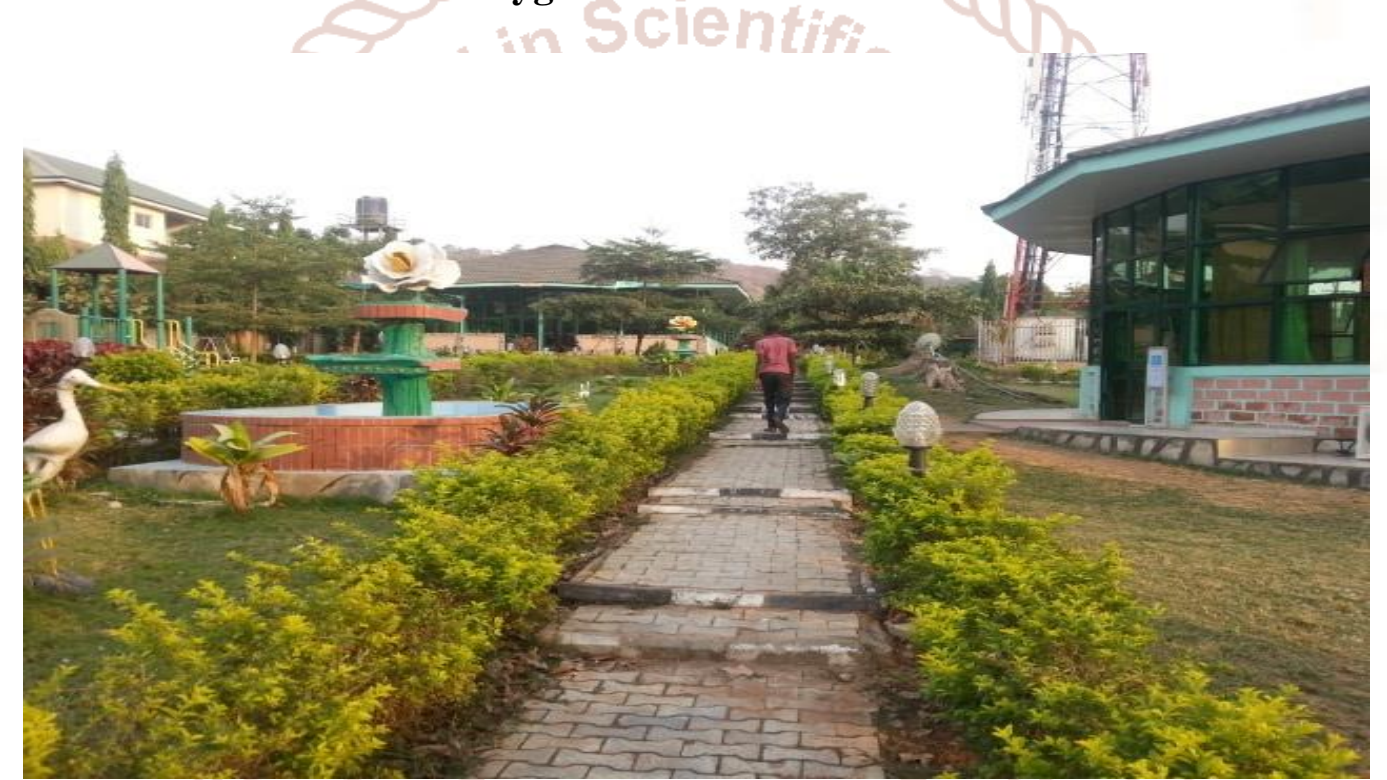

Plate 12: A View of the Gym, Restaurant and fountain

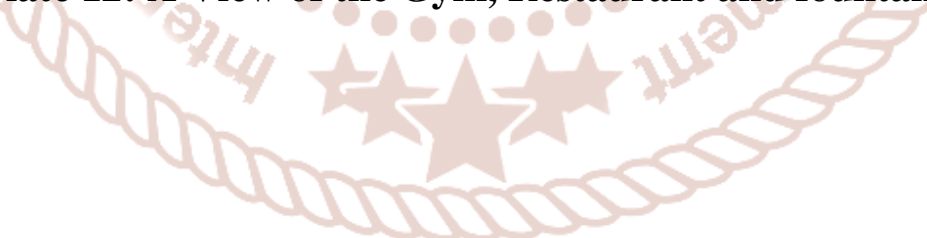

